\begin{tabular}{|l|l|l||}
\hline \multicolumn{2}{|c|}{ PublisherInfo } \\
\hline \hline PublisherName & $:$ & BioMed Central \\
\hline \hline PublisherLocation & $:$ & London \\
\hline \hline PublisherImprintName & $:$ & BioMed Central \\
\hline \hline
\end{tabular}

\title{
Different mechanisms by which CMV predisposes to CAD in men and women
}

\begin{tabular}{|c|c|c|}
\hline \multicolumn{3}{|c|}{ ArticleInfo } \\
\hline ArticleID & $:$ & 38 \\
\hline ArticleDOI & $:$ & $10.1186 / \mathrm{cvm}-2001-72060$ \\
\hline ArticleCitationID & $:$ & 72060 \\
\hline ArticleSequenceNumber & $:$ & 17 \\
\hline ArticleCategory & $:$ & Paper Report \\
\hline ArticleFirstPage & $:$ & 1 \\
\hline ArticleLastPage & $\sigma^{\circ}$ & 3 \\
\hline ArticleHistory & $:$ & $\begin{array}{lll}\text { RegistrationDate } & : 2001-10-18 \\
\text { Received } & : 2000-11-28 \\
\text { OnlineDate } & : 2001-10-18\end{array}$ \\
\hline ArticleCopyright & & Biomed Central Ltd2001 \\
\hline
\end{tabular}




\begin{tabular}{|l|l|l|}
\hline ArticleGrants & $:$ & \\
\hline \hline ArticleContext & $:$ & 1306322 \\
\hline
\end{tabular}

Joanna Lyford, Aff1

Corresponding Affiliation: Aff1

Aff1 Medwire 28-11-00, UK

Keywords

Immunology, infection, inflammation, risk factors, sex

\section{Context}

Associations between cytomegalovirus (CMV) infection and coronary artery disease (CAD) have been reported, and much current research is focused on the mechanisms by which inflammation may contribute to the pathophysiology of atherosclerosis. This new study by the authors suggests that susceptibility to CMV infection-induced CAD differs between men and women.

\section{Significant findings}

In men, an elevated CRP level was a significant determinant of CAD even after adjustment for CAD risk factors (OR 3.1; 95\% CI 1.21-7.97). CMV seropositivity was associated with elevated CRP levels on multivariate analysis $(\mathrm{P}=0.006)$. Conversely, CMV seropositivity in women was independently predictive of CAD (OR 41.8; 95\% CI 4.12-423.74). Also, CRP levels in women with CAD were over $25 \%$ higher than those without CAD, although the difference did not reach statistical significance.

Importantly, compared with CMV-negative women, CAD prevalence was higher in Ab+/Tc- and $\mathrm{Ab}+/ \mathrm{Tc}+(13 \%$ versus $68 \%$ and $64 \%$, both $\mathrm{P}<0.005)$ but not in $\mathrm{Ab}-/ \mathrm{Tc}+$ women $(25 \%)$. There were no differences in age, smoking, diabetes, hypertension and hypercholesterolemia among women with different types of immune responses to CMV infection.

\section{Comments}


These results indicate that multiple mechanisms exist whereby CMV infection and perhaps infection by other pathogens contribute to CAD. They also indicate that the relative contribution of these mechanisms to atherogenesis is sex-determined and is influenced by whether or not the host mounts an inflammatory response to CMV infection as well as by the nature of the immune response.

The authors conclude: 'These observations raise the possibility of novel therapeutic strategies for the prevention or treatment of atherosclerosis. Thus, it might be possible to alter disease outcome favorably through the use of vaccines or cytokine-based strategies designed to change an immune response directed against a causally relevant pathogen from one that conveys disease susceptibility to one that enhances resistance.'

\section{Methods}

The multicenter research team analyzed blood samples from 151 men and 87 women undergoing angiography at the Washington Hospital Center, USA. Blood samples were tested for humoral (Ab+) and cellular $(\mathrm{Tc}+)$ responses to $\mathrm{CMV}$ and for C-reactive protein (CRP); of the total cohort, CAD was diagnosed in $75 \%$ of men and $52 \%$ of women.

\section{Additional information}

\section{References}

1. Zhu J, Shearer GM, Norman JE, Pinto LA, Marincola FM, Prasad A, Waclawiw MA, Csako G, Quyyumi AA, Epstein SE: Host response to cytomegalovirus infection as a determinant of susceptibility to coronary artery disease: sex-based differences in inflammation and type of immune response.

Circulation 2000, 102:2491-2496. 2000, 102: 2491-2496. 